\author{
Bogusław Czarny \\ Chair of Economics II \\ Warsaw School of Economics
}

\title{
On Economics in Poland in 1949-1989: Introduction
}

\begin{abstract}
This article is a concise introduction into the history of economics in totalitarian Poland in 1949-1989. In it, I attempt to show the degradation of economics in Poland in this period. The main theses of the article are three. First, academic economics and the institutions necessary for the normal functioning of science were destroyed in Poland at the turn of the 1940s and 1950s. Pseudo-science was substituted for the science of economics. Second, these events had a damaging impact on the quality of research in the years that followed. In my opinion, the alleged achievements of Polish economists, e.g., Oskar Lange's monograph Ekonomia polityczna, as well as the works of Włodzimierz Brus and members of the so-called "Wakar School," were of only "local" importance. Third, after 1949 , the teaching of economics degenerated as well.

In effect, the achievements of Polish economists in the period 1949-1989 are negligible. They did not contribute significantly to the accumulation of true knowledge about the economy. Moreover, in violation of the ideals of science, Polish economists intensely indoctrinated the society, perpetuating the totalitarian system in Poland.
\end{abstract}

Keywords: pathology of science, history of economics in post-war Poland, methodology of economics

JEL: B14, B41 


\section{Introduction}

Works on the pathology of science in totalitarian states are broadly known, including sociology, philosophy and phrenology in Germany [cf., for instance, Tyrowicz 2009; Gasman 1971] and Lysenkoism, psychiatry and cybernetics in the USSR [cf., for instance, Amsterdamski 1989, Van Voren 2010, Hooloway 1974]. Studies of similar (though not identical) phenomena during the Communist regime in Poland are, however, infrequent. This article attempts to change this. My goal is to describe changes to the institutional conditions of practising and teaching narrowly understood economics in Poland after 1949. I am also interested in the ramifications of these changes. Science is a collective endeavour; I do hope that my errors will be corrected by others.

\section{Introducing Marxism into Universities}

A harbinger of change in the study of Economics at Polish universities after WWII was the so-called 'Central Planning Office Trial' or 'CUP Trial' (CUP successfully developed a Three-Year Plan for Reconstructing the Economy for the years 1947-1949). At a "discussion session" on 18-19 February 1948, economists representing the Polish Workers' Party (PPR), including Włodzimierz Brus, Bronisław Minc, Zygmunt Wyrozembski and Seweryn Żurawicki, accused the management of CUP, which was affiliated with the Polish Socialist Party (PPS), of using "bourgeois economics" rather than Marxism.

Jan Drewnowski (1908-2000), then Director of CUP’s Long-term Planning Department, wrote [Drewnowski 1974, p. 51]:

We heard for the first time... that contemporary economics should be called "bourgeois economics." It was also for the first time that in public debate people used terms like "non-Marxist" and "anti-Marxist" to discredit the opponent's arguments without considering their substance. For the first time, quotations from Marx, Lenin and Stalin taken out of context were used as magical spells to win the polemics. And for the first time was the USSR quoted as an example to be followed blindly... Clearly structured arguments bounced off a wall of intentional misunderstanding and plotted animosity ${ }^{1}$.

As a result, Hilary Minc, who ran the Polish economy, summed up the discussion by announcing that "Marxism will be introduced into universities" and CUP was closed down [Drewnowski 1974, pp. 52, 56]. The catastrophe that befell Polish economics has been described by historians, witnesses and victims. 
Jan Drewnowski [2000, p. 15] wrote about the situation at the Warsaw School of Economics (SGH): ${ }^{2}$

SGH was sovietised in mid-September $1949 . .$. It happened within the day. We were told that SGH had been nationalised, its name changed to the Main School of Planning and Statistics [SGPiS - B.Cz.]; it now had four departments, a new Rector, Professor Czesław Nowiński, as well as seven new professors. Or, to be exact, deputy professors, as none of them had academic credentials. Each of them got a new chair. Those were B. Blass, W. Brus, B. Minc, K. Owoc, L. Pawłowski, J. Z. Wyrozembski, S. Żurawicki, who were next year joined by M. Pohorille and J. Zawadzki. The incumbent professors were deprived of any influence over the running of the school. The more senior ones Professor Jerzy Loth and Professor Julian Makowski - were forced into retirement... the Pro-Rector, Professor Edmund Dąbrowski, was laid off. Other professors were temporarily allowed to keep their chairs but their teaching assignments were reduced... They were removed from their chairs in the next academic year 1950/51... This was when Professor Edward Lipiński was removed as Chair of Political Economics and I was removed as Chair of Planned Economy. Junior researchers were reduced... right away and... nearly all research associates were laid off. All $\mathrm{PhD}$ candidates were also dismissed. They were replaced at the school by nearly two dozen lecturers and several research associates, most of them PPR members from various ministries... Furthermore, many third-year students affiliated with PZPR [Polish United Workers' Party] were promoted to research associates.

New researchers who replaced the pre-war professors were described by another witness and victim of the events, Jan Rafa [1988, p. 10]: ${ }^{3}$

[They were] outsiders who had had nothing to do with science... but now had the monopoly in economics and philosophy.

And [Rafa 1988, p. 32]:

They were granted the degree of "deputy professors" and were supported by dozens of so-called deputy research associates, recruited in throngs from among the "politically aware" students.

The same happened at other universities [Rafa 1988, p. 32]:

Other higher schools were "reformed" in a similar fashion. After... such authorities as Professor E. Taylor in Poznań, Professors A. and W. Krzyżanowski in Kraków, Professor W. Styś in Wrocław, S. Zalewski in Warsaw and W. Fabierkiewicz in Łódź had been removed from research and teaching positions... a number of local figures - either 
faculty members or outsiders - were appointed deputy professors; they made up for what they lacked in expertise with obedience... and political and ideological zeal.

The situation of pre-war professors of economics varied. For instance, Edward Lipiński (1888-1986), who was not allowed to teach the theory of market cycles and economics at SGPiS, remained the Editor-in-Chief of "Ekonomista" (as a fig leaf for a new board of editors) and lectured on the history of economics at Warsaw University ${ }^{4}$. Adam Krzyżanowski (1873-1963), who had been Oskar Lange's tutor before the war, lived in poverty [Lange 1986, p. 524]. Aleksy Wakar (1898-1966), the Rector of SGH in 1946-1947, who converted to Marxism and joined PPR, was thrown out of the party and banned from teaching in 1950, and detained and handed over to the Soviet authorities in the summer of 1952 [Kaliński 2006, p. 10]. He came back to Poland after three years in a work camp.

In this context, Drewnowski [1974, p. 58] writes:

Eight researchers in economics alone, whom I knew personally, were detained and jailed for several years without a reason.

After 1956, some pre-war professor, including Edward Taylor (1884-1964), were reinstated. However, in the meantime, they had not been allowed to leave the country or to order books. As a result of this, and also due to their age, they had little clout in the alien research teams within which they were placed. As an important exception, Wakar headed the Chair of Political Economics at SGPiS after his return from the work camp until his death in 1966, giving rise to the Wakar School.

At that time, after 1949, political economics was introduced into the curricula of all university programmes [Drabińska 1992, p. 43; cf. Fijałkowska 1985, pp. 26, 181]. PZPR units were set up at university departments and chairs. Party secretaries had more clout than rectors, deans and chairs (the Union of Academic Polish Youth, or ZAMP, had a similar function in the student body). Universities were assigned "supervisors" - political police officers, and some faculty members were confidential informants and provided intelligence on their co-workers' opinions and conduct [Z. Ż. 1998, p. 11; cf. Kossecki 1999, p. 326]. A person's political stance became a key criterion of promotion to major academic positions and in the recruitment of research associates.

The operation put an end to the autonomy of universities. From 1949 on, the minister appointed and dismissed rectors, deputy rectors, deans and deputy deans [Herczyński 2008, p. 118; cf. Hübner 1992, pp. 592-594]. For example, Wincenty Styś (1903-1960), ${ }^{5}$ a pre-war lecturer at the Lviv Polytechnic and the Jan Kazimierz University of Lviv, was repressed by the authorities and had to withdraw from public life after 1948. He was elected Rector of Higher School of Economics (WSE) in a free election in 1956. Professor Styś was re-elected Rector by WSE faculty in 1959 but the minister refused to approve his appointment. 
Interventions by the authorities reached down to file-and-rank faculty members. For instance, Stefan Kurowski (1923-2011) was deprived of his Dr habil. degree (habilitation) which he had earned in 1960 for a study that was critical of the Socialist economy. Likewise, Janusz Gedymin Zieliński (1939-1979), "probably the most prominent post-war generation Polish economist of the 1960s," was removed from the Wakar Chair in 1963 [Beksiak, Grzelońska 1990; Zieliński 1973].

The operation which "introduced Marxism into universities" culminated with the address of its sponsor, Oskar Lange (1904-1965), at the opening session of the Economist Congress in December 1950 [Lange 1951, pp. 4-5]:

In order to live up to the challenges ahead, Polish economics must become a Marxist-Leninist science. To this aim, it must completely overcome the remains of bourgeois thought... which stand in the way rather than contributing to the achievement of the tasks faced by the Polish economy...

The "overcoming" was described by the keynote speaker of the Congress, Włodzimierz Brus (1921-2007):

The most characteristic trait of the past period... in economics was the cut-throat struggle of the Marxist-Leninist theory of economics against false bourgeois theories. As a result of this ideological offensive, conducted under the leadership of the party, we can identify a number of major successes which create positive conditions for growth of our economics research centres [Brus 1951, p. 32].

As an example of "false bourgeois theories," Brus named among others the work of "ultra-reactionary American behaviourists in economics," John von Neumann and Oskar Morgenstern's 1944 Theory of Games and Economic Behaviour [Brus 1951, p. 22]. The successes he mentioned included the publication of huge editions of Marxist classics, including Stalin, translations of works of Soviet economists, as well as the prevalence of Marxism in Polish economic journals.

In summary, world-class professors were removed from Polish economics universities after 1949. Their teams of researchers and teachers were disbanded, which crushed the centres of independent thought set up at a great expense by individuals who had survived the war and the onslaught of the Polish intellectual elite. As for the people who replaced the pre-war professors, according to Drewnowski, "none of them had academic credentials."

Self-perpetuation of that system was spurred in the coming decades by implementing new criteria for the recruitment of researchers. Department heads were prone to recruit helpers much akin to themselves. The selection mechanism based on cognitive success was destroyed and replaced by ideological loyalty and usefulness to superiors. As a result, 
more often than not, most of the faculty at economics departments were card-carrying members of PZPR.

\section{Destruction of Other Scientific Institutions}

The Polish Economic Society (PTE), founded in 1945, was turned around in the 1940s and 1950s. The elite association of researchers was made into a mass organisation which served the totalitarian state as a tool of indoctrinating the general public. ${ }^{7}$ The by-laws of PTE were amended in 1949: the Research Council was replaced by a Research Board, which supervised the Society's research and publication initiatives [Orłowska, Orłowski 1985, p. 54]. The Board members were: O. Lange (Chair), E. Lipiński (Deputy Chair), F. Blinowski, W. Brus, B. Minc, J. Tepicht, J. Wyrozembski, S. Żurawicki. Janina Orłowska and Tadeusz Orłowski [1985, pp. 31-32] wrote rather euphemistically:

A number of long-time activists were no longer allowed to actively participate in and run the affairs of PTE. A new group of leading activists of the Society recruited from among Marxist economists gave the organisation a direction that was in line with contemporary political and economic developments.

From that time on PTE, like other research associations, was to operate "under the supervision" of the Polish Academy of Sciences (PAN).

The Society embarked on the path of broader impact on public opinion by explicating the assumptions of the economic policy of the party and the government. Marxist political economics became the main foundation of both research and practical activity. [Orłowska, Orłowski 1985, pp. 32-33; cf. pp. 64, 68, 71, 87-88].

The transition of Polish economics also required control of the media. From 1945, this was helped by censorship, rationing of paper and access to printing facilities. The decisive step came with the nationalisation of publishing houses including Gebethner i Wolf and Trzaska, Evert i Michalski. As of 1951, they were replaced by state publishing institutions controlled by party activists, for instance Książka i Wiedza (KiW), established in 1948, whose Editor-in-Chief was Roman Werfel, later the Editor-in-Chief of the PZPR Central Committee official journal "Nowe Drogi”. Polskie Wydawnictwa Gospodarcze (Polgos) was founded in 1949 and renamed Państwowe Wydawnictwo Ekonomiczne (PWE) in 1961 (Edward Łukawer, an activist of the Union of Polish Patriots (ZPP), was the Editor-in-Chief of Polgos as of 1950). Państwowe Wydawnictwa Naukowe (PWN) was founded in 1951 and its Editor-in-Chief was Tadeusz Zabłudowski, former head of censorship. These publishing houses banned all the unorthodox books [cf. Kondek 1993]. 
Witold Krzyżanowski, pre-war professor and member of the Kraków chapter of PTE, criticised the practice at the Second Polish Economist Congress [Dyskusja na II Zjeździe... 1956, p. 122]. The contemporary atmosphere was described in a statement from Wincenty Styś, who talked about "secret reviews" and protested against distortions of research publications by publishing houses:

It is unacceptable for publishing houses to insert pages and pages of text before publication without consultation with the author [Dyskusja na II Zjeździe... 1956, p. 126; cf. point 4 of the Resolution of the Second Polish Economist Congress in Warsaw on 7-10 June 1956, in: “Uchwała...” 1956, pp. 150-151].

The "secret reviews" that Styś mentioned were publishers' reviews kept away from the authors.

Rafa [1988, p. 55] writes:

It was at that time that the concept of "blacklisting" was conceived: lists of books which were not to be read and especially not to be recommended to students. The only difference between what NSDAP had done... with "ideologically alien" books from the Third German Reich after Hitler's ascension to power and what PZPR did at that time was that such books were not burned in Poland after 1949.

And:

However, such books were shredded... F. Benham's textbook of political economy, translated in a POW camp [edited by Jan Drewnowski - B.Cz.] and published in 5,500 copies in 1948, sold only half of the copies while the others were shredded.

Rafa also writes about "'black lists' of people who not only were not to be hired in schools but whose papers must not be published and those already published must not be quoted" and names several names (A. Krzyżanowski, E. Lipiński, E. Taylor, J. Drewnowski, S. Zaleski) [Rafa 1988, pp. 10-11].

The situation of economics journals after 1949 is exemplified by the story of "Ekonomista". The members of its board of editors until 1948 were: A. Krzyżanowski, E. Lipiński, E. Taylor, S. Zaleski. From 1949 on, there was a new board of editors: B. Minc, E. Lipiński, W. Trąpczyński, z. Wyrozembski. Thus, "Ekonomista" was taken over by Marxist economists.

The destruction of economics in Poland was helped by the Institute for Education of Research Faculty (IKKN), ${ }^{8}$ established at the Central Committee of PZPR in 1950 [Connelly 1996; Czarny 2014b]. Adam Schaff (1913-2006) was appointed IKKN Director. "Candidates of Sciences" educated at IKKN (the Soviet degree replaced the PhD in 1951) were appointed to replace faculty members removed from universities. Rafa wrote about the "second wave" of economists of the new type who started their university careers in 
the mid-1950s [Rafa 1988, p. 33; cf. Drewnowski 1974, p. 59]. In this connection, Rafa mentioned Maria Ciepielewska, Henryk Chołaj, Zbigniew Grabowski, Kazimierz Łaski, Mieczysław Mieszczankowski, Mieczysław Nasiłowski.

Eventually, the Central Qualification Board for Research Faculty was established in 1951. A thicket of legislation on academic degrees and titles was spreading, allowing the government to control academics throughout their career paths. The requirement of competing for degrees and titles, and consequently having to win the favours of potential examination board members, reviewers and others, was conducive to conformist attitudes and negative selection [Hübner 1992, pp. 654-659; cf. Haugstad 2008, pp. 213-244].

\section{Impact of the Transition on Economic Research and Teaching}

The developments described above were decisive to the course of Polish economics in the period 1949-1989. ${ }^{9}$ The ramifications included costly mistakes by economic policy-makers. For example, CUP was closed down and replaced with the State Board of Economic Planning (PKPG), which followed Soviet planning methods. This was the main reason for the well-known problems with the implementation of the Six-Year Plan. The sections below only discuss scientific research and the teaching of economics.

\section{(a) Scientific Research}

The quality of research plummeted after 1949 as research was decoupled from the real economy, not least because the government discontinued the publication of key economic statistics. Political usefulness of official declarations prevailed over their truthfulness; thus, economics was replaced by pseudo-science. ${ }^{10}$

The transition of economics into pseudo-economics was documented by Stefan Kurowski in his presentation at the Second Polish Economist Congress [Kurowski 1957]. To avoid an open conflict with Marxist dogmas, many economists shied away from economic theory and focused on "safer" disciplines: the history of economics, statistics, and econometrics. A "sycophant science" flourished, praising economic policy-makers [Kurowski 1957]. For instance, Ekonomista practically stopped publishing research papers as of 1949. At that time, the directions of economic research were set in the party-sponsored journal Nowe Drogi [Grzelońska 2006, p. 54].

A certain change took place in 1956. The Polish economists working in Poland in 1956-1989 who are usually considered to be most prominent include Michał Kalecki (1899-1970), Oskar Lange, Włodzimierz Brus and Aleksy Wakar (along with the Wakar School). I will limit myself to commenting on their work.

First of all, in my opinion, Michał Kalecki was, to a certain extent, an outsider in the economist community that was created after 1949. He owed his position in the scientific community to his intellect and work rather than to the powers that be. Lange was in 
a similar position; however, Kalecki came back to Poland in 1955 rather than 1947 so, unlike Lange, he did not participate in the operation that replaced Polish economics with a pseudo-science. Furthermore, Kalecki was not a party member, nor did he ever pay the regime a tribute as compromising as Lange's eulogy to Joseph Stalin. In a 1953 collection of three works Zagadnienia ekonomii politycznej w świetle pracy Józefa Stalina pt. Ekonomiczne problemy socjalizmu w ZSRR (Aspects of Political Economy in the Light of Joseph Stalin's Economic Problems of Socialism in the USSR), Lange [1953a, p. 64] wrote:

Stalin's Economic Problems of Socialism in the USSR with ingenious simplicity and acuity captures the character and nature of economic laws under Socialism...

Lange's address at PAN's First Scientific Seminar after the death of Stalin, entitled Joseph Stalin's Last Contribution to Political Economy [Lange 1953b, p. 27], gained much notoriety:

Stalin's genius was expressed in clear and simple thoughts, thoughts that were able to capture the most profound and difficult issues of historical development of nations in a manner comprehensible to the common man.

Indeed, Kalecki also happened to write about "the science of historical materialism," "the degeneration of monopolist Capitalism" and "the trade unions harnessed to the chariot of imperialism" [Kalecki 1956, p. 11]. However, rather than legitimising the totalitarian system with his work, as Lange did, Kalecki focused on researching the Polish economy. This put his loyalty to the system in question. No later than thirteen years after his return to Poland, the government (and the economist community created after 1949) got rid of Kalecki during the "March events" of $1968 .{ }^{11}$

Second, I do not think that Lange's post-war work was particularly noteworthy. Not without reason did Don Patinkin, Lange's famous student in Chicago, write that post-war Lange was a tragic figure [Patinkin 1981, pp. 8-9; cf. Czarny 1989a, Kurowski 2007, p. 44]. I do not believe that Lange's Ekonomia polityczna [Political Economy] was a milestone in global economics. Lange's fame in Poland was driven by his prior repute earned in the West, the low quality of publications by others, and censorship which silenced the critics. Globally, Political Economy received run-of-the-mill reviews, mainly in Socialist journals [Lange 1986, pp. 761, 801, 864, 907, 915-916]. Journals such as the "American Economic Review" passed over it in silence.

The prominent Sovietologist Peter Wiles of the City University of New York was very critical of Political Economy [Wiles 1965]. He enumerated the cardinal weaknesses of Political Economy: it painted an untrue picture of the economy of Communist-governed countries; it ignored Keynesianism; it failed to mention that the increase of real salaries in Capitalist countries contradicted Marxism and that surplus value is not empirically measurable; it ignored the market as a mechanism conducive to socially rational allocation 
of resources in Capitalism; it did not include services in the calculation of national income [Wiles 1965, pp. 119-122].

The concept of rationality of economic management, outlined in Chapter 5, which Lange himself believed to be his main achievement, was considered by commentators to be a mere vindication of real Socialism (cf., for instance, [Godelier 1972, p. 20]).

Third, the work of Włodzimierz Brus merits some comment. Brus unexpectedly changed his views after 1955. From that time on, Brus (and others) called for "application of the law of value" in the economy. The intention was to restructure the system set up (by the proponents of the change and their co-workers) in the late 1940s. They usually meant decentralisation of the economy, partial opening up of the markets and, sometimes, ownership changes. Brus's proposals put forth in Ogólne problemy funkcjonowania gospodarki socjalistycznej [The General Problems of the Functioning of the Socialist Economy] (1961) went in the same direction.

However, the advantages of the market and the importance of incentives derived from ownership had been discussed before Brus in economic textbooks around the world, also in Poland (cf., for instance, [Taylor 1947, pp. 54-57; 113-124]). Consequently, I believe that Brus and others rediscovered the wheel and stumbled upon well-known truths they were ignorant of in the absence of a regular background in economics, one they never had also because they themselves destroyed academic economics in Poland. Hence, it would be difficult to hold their concepts as representing substantial theoretical achievements, especially in the global scale. However, Wagener emphasises Brus's contribution to the explication of the shortcomings of the command economy [Wagener 1998, p. 5].

Fourth, the pragmatists of the Wakar School merit special attention. As they considered other solutions to be unrealistic, they accepted the monopoly of the state in planning while striving to improve the system of corporate management. This involved the traditional "command economy" ("direct account") versus the "parametric system" where enterprises are encouraged to deliver the targets set by the state among others by means of prices. The Wakar school dilemmas were described by Janusz G. Zieliński [1973]:

Starting in 1960, Professor Wakar and I began to work on our theory of direct economic account and mainly focused on analysing the "logic" of its limitations as well as the options for improvement of a centralised system rather than supporting decentralisation... We concluded... that far-reaching reforms towards a "directed market" would be unacceptable... at least in Poland. We were left with only two options. The first one was to continue working on postulative models... This was tantamount to reducing our active participation in discussions on economic policy, limiting our contacts with economic practitioners, and abandoning all hope that we could come up with constructive proposals of improving the existing economic system, be they piecemeal and of third rank. The other option was to analyse the existing economic mechanism 
and to reveal its inherent weaknesses while searching for and supporting all feasible improvements to it. That was the option we went for...

I believe it is important to note that members of the Wakar School taught economics. Despite its shortcomings, their 1972 textbook Ekonomia polityczna socjalizmu (Political Economy of Socialism) is a unique attempt at bringing such concepts of global economics as the Pareto optimum and the Edgeworth box into the fold of political economics of Socialism [Ekonomia polityczna... 1972, pp. 127-139].

The pathology that would consume the Polish economy from 1949 was alleviated in 1956 but spiked once again in the late 1950s and during the "March events" of 1968. Michał Kalecki and his co-workers Kazimierz Łaski (b. 1921), Ignacy Sachs (b. 1927), and Jerzy Osiatyński (b. 1941) left SGPiS. Janusz G. Zieliński was dismissed from SGPiS. ${ }^{12}$ Edward Łukawer (1920-2007) was dismissed from the Kraków Academy of Economics. The revolution devoured its own children. For instance, Włodzimierz Brus, who was directly responsible for the Stalinisation of Polish economics, was removed from the University of Warsaw during the anti-Semitic campaign (Brus was Jewish) [Brus, no publication date]. March 1968 in Polish economics at SGPiS was described by the editors of "Gazeta SGH" [Gazeta... 1998] and Osiatyński [1984]. ${ }^{13}$

Publishing houses supported censorship throughout the period 1956-1989 just like after 1949. Publications were infused with ideology under pressure exerted by reviewers and editors. Faced with a choice between publication of a distorted work and no publication at all, the authors caved in. Rafa [1988, pp. 70, 134] wrote about publishing houses which "effectively blocked the publication of genuine scientific works". The concept of "blacklisting" lived on; for instance the works of Zieliński, who had migrated to the UK, were banned in Poland [Beksiak, Grzelońska, 1990; cf. Grzelońska, 1989].

Despite the debate at the Second Polish Economist Congress, the membership of the PTE Board and the board of editors of Ekonomista remained largely unchanged. As late as 1988, Rafa reported on "in-house censorship" at "Ekonomista", "where any 'non-class-aware' paper would be rejected [by the board of editors - B.Cz.] even before being submitted to the censors" [Rafa 1988, p. 70; cf. p. 134]. I myself had first-hand experience of a similar practice of the editors of "Ekonomista" in the 1990s. Consequently, in the 1960s, 1970s and 1980s, "Ekonomista" published scores of papers on the basic economic laws under Socialism and the advantages of Socialist ownership of the means of production. Conversely, game theory and the implications of hidden unemployment in Poland were hardly ever discussed in the journal.

Instead, pointless debates continued for years, among others in "Ekonomista," such as the debate on the rationality of management in different economies, initiated by Lange in 1959, which degenerated completely in its final phase in the 1980s [Czarny 1989b]. Not much different was a series of eulogies to "well-developed Socialist society" published 
in the Polish economic literature in the late 1970s, mainly owing to H. Chołaj, a member of the board of editors of "Ekonomista".

Thirty-five years later, in 1986, Wiktor Jarmulicz [1986, pp. 24-25] $]^{14}$ described the status of Polish economics:

The fruit of the seeds sown 35 years ago is more than evident. An exceptionally low quality of the research faculty accompanied by a terrifying collapse of economic thought in Poland; resulting in an extremely low level of Poles' economic knowledge... Indoctrination has taken its toll; its alarming results will stay with us for long.

Rafa [1988, p. 41] shares this opinion:

[A] significant, enduring and... long-term result of the carnage of Polish economics in 1949 is its lasting devaluation...[W]ith a handful of exceptions, the thousands of 'scientific' publications from the period 1950-1985 have little if anything to do with science.

Grzelońska [2006, p. 59] is only slightly more optimistic about the status of Polish economics:

After the war... Polish and global economics stayed apart. Personal relations between Polish and foreign economists from the end of WWII remained largely ceremonial, limited to socializing... This was brought about by the widening divide between Polish and global economics in terms of research, topics and methodologies.

Marek Ratajczak [2009, p. 11] wrote on the same note:

Polish economics carried the stigma of marginalization in mainstream world economics. An illustration of this was that in world economics the two figures most closely associated with Poland continued to be the long-deceased O. Lange and M. Kalecki.

\section{(b) Teaching Economics}

The quality of teaching economics plunged after 1949. The pluralism of presented views was gone. The curricula were developed by the ministry and distributed to universities. ${ }^{15}$ They were soaked in ideology, promoted among others in textbooks. A selection of quotations:

The existence of... capital... relies on exploitation of the working class, on social relations where one man, just because he owns the means of production, can appropriate a part of the products of other men's work. This is how the Capitalist can exploit the working class. 
There exist four Capitalist groups: industrial, commercial, the group dealing with financial operations, and... the group of landowners. The income of these... groups derives from a common source: the overall mass of appropriated... surplus value. [Schaff, Brum, 1950, pp. 64, 65]

With his analysis of Capitalist relations, Marx proved the existence of the two main laws of Capitalism... One of those is the advancing relative pauperisation of the working class, the other law concerns its absolute pauperisation... Absolute pauperisation is evidenced... by a decrease of workers' real wages... Data from US Army draft medical checks indicate that half of the young conscripts were considered... unfit for military service... the reason for their non-eligibility in the majority of cases was the poor diet of US workers, especially the Negroes. [Minc 1949, pp. 187, 189]

[S]ocialist industry and the great Socialist agricultural economy are the world's most centralised and most mechanised even as they continue to grow at a rate that Capitalism could never achieve.

At the stage of Communism... work will have been transformed from a source of income... into life's main necessity... All people... will be cultured and broadly educated, and able to freely choose a profession... The highly developed production capacity and productivity of social work will make all material and cultural goods ample, paving the way for transition from the Socialist principle of distribution to the Communist principle... "From each according to his ability, to each according to his need." [Ostrowitianow et al. 1955, pp. 734, 375-376]

While tuition fees at universities were abandoned, which allowed for universal economic education (with working class and farmer students predominating both in recruitment and throughout university programmes), the quality of the programmes was disastrous. In 1957, Kurowski wrote:

Teaching political economics... has turned into a vicious circle of newspeak with petrified quotes replacing thinking and the cynicism of lecturers and the mendacity of students replacing the belief in the eternal values of science and truth... This has left hundreds and thousands of people who... have entered adulthood deprived of the faculty of thinking... and of any intellectual interest, dumbfounded as they were by the pointlessness and vastness of the apparent knowledge which they had had to absorb, illiterate in vast areas of economic thought... they have graduated... from universities of economics ignorant of the economic situation of their own country... oblivious to statistics and the basic professional and scientific tools of an economist, they have gone bust upon their first encounter with real life. [Kurowski 1957, pp. 299-300]

The situation did not change much after 1956, as evidenced by the contents of academic economics textbooks from the 1960s, 1970s and 1980s. Selected quotes: 
As the owner of all invested capital, the Capitalist is the owner of products manufactured by the workforce. Thus, on the market, he cashes in on the products manufactured by the worker. Therefore, he collects both the invested capital and the surplus value... The workforce creates all new value produced at any given time. The bigger the part of that value appropriated by the Capitalist... the greater the part of labour that the worker has to give to the Capitalist and the lesser the part he keeps for himself. [Sadzikowski 1969, pp. 182-183]

The Socialist economic system is such that (1) in contrast to Capitalism, dominated by private property, the main means of production are socially owned. Under those circumstances, (2) direct economic activity is subordinated to material and cultural needs of the society... (4) All generated national product is distributed by the Socialist state in accordance with the current and prospective needs of the society... Social ownership of the means of production also implies elimination of the Capitalist principles of distribution based on economic exploitation of one class by another class...[Ekonomia... 1974, pp. 13-14]

The... transformations of imperialism which play a significant role in maintaining and even amplifying its expansive and exploitative character include the development of international monopoly corporations. They are in fact a new, higher form (as compared to the former cartel form) of international monopolies which have become the key actors responsible for economic and political dependence of developing countries on imperialist countries. A specific form of international monopolies are international economic treaties (e.g., the European Economic Community). [Mieszczankowski 1987, p. 270]

Textbooks were complemented by other publications, such as Mała Encyklopedia Ekonomiczna (The Small Encyclopaedia of Economics), which featured entries like the one below:

BASIC LAW OF SOCIO-ECONOMIC FORMATIONS, economic law which identifies the main actors and the main processes of development of any $\rightarrow$ socio-economic formation, i.e., the goal of production and the means to that end; it derives from objective conditions of a formation, its $\rightarrow$ relations of production, in particular the type of ownership of $\rightarrow$ means of production... [B] asic economic law of Capitalism to produce as much surplus value for Capitalists as possible through expansion of production, technology development and increasing exploitation of the workforce... [B] asic economic law of Socialism - to continuously grow and improve production based on leading technology in order to best address constantly growing needs and ensure comprehensive development of society members. (J.Za. [Józef Zawadzki B.Cz.]) [Mała... 1961, p. 514] 
Law of conformity of productive forces and relations of production... LCPFRP also operates in the Socialist formation. Here, the tensions... arising between relations of production which lag behind and new productive forces do not create serious socio-economic conflicts... [T] hese are timely eliminated thanks to conscious activity of the Socialist state. Relations of production are promptly brought back to conformity with the achieved level of productive forces owing to the alignment of the interests of all classes and layers of the Socialist society; there are no social forces here interested in maintaining obsolete forms of Socialist relations of production. (A.R. [Adam Runowicz - B.Cz.]) [Mała... 1974, pp. 626-627]

No wonder that, despite the liberalisation in 1956 and then in the 1970s and 1980s, Jarmulicz shared in 1986 the observations made by Kurowski in 1957:

The transformation of economics into a tool of social indoctrination 35 years ago has produced most deplorable results. Teaching the political economics of Socialism for more than three decades has numbed the minds, which are now unable to comprehend economic issues, and wreaked havoc in the heads of most adult Poles. [Jarmulicz 1986, p. 24]

\section{Comments}

Setting aside Kalecki, the achievements of Polish economics in 1949-1989 turn out to be scarce at best. The works of Lange, the late Brus, and the Wakar School were hardly superior to anyone else's. Those works were prominent only locally. They sparked but transient interest abroad, often for reasons that were off-topic (those works were harbingers of political change in Poland). That there is little mention of such works in global economic publications after 1990 is the best proof of this. A review of encyclopaedias, lexicons and textbooks of economics that are popular around the world corroborates this view [cf. Czarny 2014a]. Similar conclusions were drawn by Hans-Jürgen Wagener in the summary of results of an extensive research project that aimed to evaluate the achievements of economics in five of the countries of real Socialism [Wagener 1998, pp. 1, 5, 16, 24-27; Wagener 1997)].

The picture of Polish economics in 1949-1989 is even more bleak if one considers not only its successes but also its sins. After all, Polish economists indoctrinated the general public throughout that period. There is ample evidence of such indoctrination, for instance economic publications, textbooks and encyclopaedias of the period, as well as dozens of issues of "Ekonomista" which published articles glorifying real Socialism. In violation 
of the eternal ideal of truth, Polish economists lied for 40 years to millions of students, readers, viewers and listeners, concealed from them the existence of the true economics and enjoyed the benefits of it all. In exchange, they recommended works full of omissions and false science. The fraud they committed wasted everyone's time, corrupted young people's minds, degraded economic knowledge of the general public, and perpetuated the totalitarian system.

As a result, the ethos of an economic scientist in Poland was discredited. The symptoms of the degradation are many; they are diverse and broadly known. I have described elsewhere the forged translation into Polish of a critical debate that followed the presentation of Aleksander Łukaszewicz and Zdzisław Sadowski (Editor-in-Chief of "Ekonomista" and Honorary Chair of PTE) at an international conference [Czarny 2010, p. 60]. However, most cases were less spectacular and more commonplace: obtaining public funding for fake research and pseudo-education; organising conferences only to legitimise alleged research activities of attendees; forging lectures, classes, examinations and competitions; nepotism; plagiarism; tacit approval of mass fraud committed by students ("cribbing"). The degeneration of the community created by a political decision years ago is evidenced among others by the swift transformation of views represented by the luminaries of Polish pseudo-economics depending on the current political climate. ${ }^{16}$ Similar conclusions arise from observations concerning the exchange of reviews among researchers, legitimising their and their protégés' alleged research, as well as "surrogate vengeance," where students of the opponent are prevented from earning an academic degree by, for instance, means of manipulated reviews.

On a side note, US and Polish historians and commentators reported after 1989 that Lange had begun to work with the Soviet intelligence in the 1940s. Tadeusz Kowalik denies the allegation [Smyrgała 2009; cf. Kowalik 2008, Vol. 4, p. 874]. In 2000, Arcana reported that Brus had worked with the political police of Poland and of East Germany [Szarek 2000; cf. Sawicki 2002]. According to the files at the Institute of National Remembrance (IPN), Zdzisław Sadowski collaborated with the Polish security service [Marosz 2008].

Little wonder, then, that Ratajczak [2009, p. 13] considers it "noteworthy" that, after 1989 , some people suggested a clear break with the previous system: ${ }^{17}$

This would have involved invalidating academic degrees and titles awarded in the Communist era, or at least... re-verifying them with the help of invited Western economists... [T] here was no change in academic staff, for example by imposing premature retirement onto those whose entire academic careers had been formed in the People's Republic of Poland.

It was also proposed to ban people without a scientific degree earned at a renowned Western university from holding managerial positions at publicly financed research institutes. None of those proposals were put in place. Thus, after 1989, economics in 
free Poland remained the same pseudo-science that had monopolized the People's Republic of Poland since the 1940s; that is, a collection of ideological principles derived from Marxism that were largely decoupled from the very market forces that Polish economists would now be tasked with deciphering.

\section{Notes}

${ }^{1}$ All quotations are translated for this article, unless otherwise indicated.

2 The decision to set up SGPiS was made by the Political Bureau of the Central Committee of the Polish United Workers' Party [Drabińska 1994, p. 68].

3 This was the pen-name of Professor Józef Nowicki (1917-1989), who studied at the Warsaw School of Economics, worked as Chair of Political Economy at SGPiS, and was a historian of economics (he published, among others, Teoria ekonomii II Rzeczpospolitej, KiW, Warsaw 1988).

${ }^{4}$ It was probably important that Lipiński accepted supervision of the doctoral theses of W. Brus, B. Minc, z. Wyrozembski, M. Pohorille and J. Zawadzki (cf. Drabińska 1992, p. 141).

${ }^{5}$ Styś was one of the founders of Wyższa Szkoła Handlowa, a college that was nationalised and renamed Wyższa Szkoła Ekonomiczna in 1950, once again renamed Akademia Ekonomiczna im. Oskara Langego we Wrocławiu in 1974. It was renamed Uniwersytet Ekonomiczny in 2008 (the name of Oskar Lange was skipped).

${ }^{6}$ The paper delivered by Brus, aged 29, who had no PhD yet in 1950, was probably penned by a group of party member economists.

7 The transition of PTE was part of the operation designed to take autonomy away from research associations. Several institutions were closed down including Polska Akademia Umiejętności and Towarzystwo Naukowe Warszawskie. They were replaced in 1951 with the Polish Academy of Sciences (PAN), supervised by the prime minister and his deputies, according to the Soviet model.

${ }^{8}$ IKKN was renamed the Institute of Social Sciences in 1953, once again renamed Higher School of Social Sciences (WSNS) in 1958, and merged with the Institute of Marxism and Leninism to form the Academy of Social Sciences in 1982.

9 The period was far from uniform. The years 1949-1955 were the Stalinist era. Liberalisation took place in 1956-1967, followed by a period of more restrictive government policy. In 1968-1989, more openly critical works were published and researchers visited Western universities more freely. Nonetheless, Marxism retained its monopoly in Poland throughout that entire period and political criteria were key to publications and careers [Kurowski 2007, p. 50].

${ }^{10}$ Pseudo-science is understood here as knowledge or activity pretending to be science yet contradictory to the scientific method, lacking in empirical or logical grounding. It includes, without limitation, exaggerated, unclear, contradictory and unverifiable statements [Hansson 2012; cf. Thagard 1978; cf. Lakatos, 1974]. I believe that, like astrology, Polish economics after 1949 was not a "degenerating scientific research programme" (Lakatos) but a pseudo-science. Degenerating scientific research programme is pseudoscientific if and only if 1 ) it has been less progressive than alternative theories over a long period of time, and faces many unsolved problems; but 2) the community of practitioners makes little attempt to develop the theory towards solutions of the problems, shows no concern for attempts to evaluate the theory in relation to others, and is selective in considering confirmations and disconfirmations [Thagard 1978, p. 228]. After all, many Polish economists did not strive for the truth but followed the principle of 
party influence over science ("zasada partyjności nauki") and supported real Socialism with propaganda [cf. E. Adler, 1953]. Out of 41 participants of the Second Polish Economist Congress in 1956, only Styś endorsed Kurowski's postulate of scientific freedom.

11 A comparison of the funerals of Lange and Kalecki takes on a symbolic dimension. Lange's funeral had all the features of the obsequies of a party dignitary. There were no speeches at Kalecki's funeral: Kalecki, who was removed from SGPiS and withdrew from public life, forbade any funeral speeches [Lange 1986, pp. 933-945; Łukawer 2006, pp. 9-10]. 1979.

12 Janusz Gedymin Zieliński committed suicide as an émigré in the United Kingdom on 8 August

${ }^{13}$ After March 1968, the position of associate professor (Dozent) was opened to PhDs without habilitation. This allowed some newly vacated lines to be filled, as a form of reward, by academics who had proved themselves to be loyal in the "March events," as per the opinion of Party (PZPR) functionaries within the universities. This often happened at economics schools and departments of economics. The new appointees were expected to ensure that students would be taught in politically correct ways.

14 This was the pen-name of Wiesław Samecki (1927-2007), who worked at the Institute of Political Economy, University of Wrocław; he was a student of Wincenty Styś (he published, among others, Centralny Okręg Przemysłowy 1936-1939, Wrocław 1998).

15 "Ekonomista" No. 2 of 1950 published guidelines drafted by IKKN entitled Przykładowa tematyka rozpraw dla uzyskania stopnia naukowego w zakresie ekonomii politycznej [Examples of topics of theses of candidates for an academic degree in political economy].

${ }^{16}$ For instance, in 1953, Edward Lipiński criticised his own statements about economic laws as "anti-Marxist", namely, insufficiently attentive to the objective nature of the laws [Lipiński 1947; cf. Lipiński 1953, p. 51]. In the same article, Lipiński described the "law of planned (proportionate) development of the Socialist economy" as opposed to the anarchy of production under Capitalism, which he took back three years later [pp. 47, 49; cf. Lipiński 1956, pp. 28, 32]. In 1952, Gabriel Temkin wrote about the "basic economic law of Socialism," which he denied in 1962 [Temkin 1952, p. 26; cf. Temkin 1962, p. 41]. The debate on the "well-developed Socialist society" initiated by Henryk Chołaj in the 1970s ended abruptly after the economic crisis of the 1970s and 1980s. In the 1980s, Józef Pajestka (Editor-in-Chief of Ekonomista and Chair of PTE) initially claimed that the economy of the People's Republic of Poland exhibited high macroeconomic rationality of management, only to conclude later that the same economy was completely non-rational at the macroeconomic level [Pajestka 1980, p. 290; cf. Pajestka 1982, p. 353 and Pajestka 1988, pp. 282-283].

17 For instance, in 1998, Ludwik Skiba wrote: "Germans, Czechs, Estonians fearful of a come-back of a peculiar Marxist ethics have decided to significantly reduce those academic faculty members who... were distinguished as servile to the party and the government. We, in turn, have been given a 'broad line' policy which entails amnesia as a means of getting a comfortable life during the transition. Today it is a good policy to close your eyes to the sins of the past." [Skiba 1998, p. 13].

\section{References}

Adler E., (1953), Partyjność filozofii i nauki, “Nauka Polska”, No. 2.

Amsterdamski S., (1989), Życie naukowe a monopol władzy casus Łysenko, in: Łysenko i kosmopolici, Warszawa.

Beksiak J., Grzelońska U., (1990), Janusz Gedymin Zieliński. Wspomnienie, “Gazeta Wyborcza”, 9 April. Brus W., (1951), O stanie nauk ekonomicznych w Polsce, "Ekonomista”, No. 1.

Brus W., (unknown date), Zmora reformowania socjalistycznego systemu ekonomicznego (nota biograficzna) (retrieved 9.03.2013, from www.pte.pl/pliki/doc/WlodzimierzBrus.doc). 
Connelly J., (1996), Internal Bolshevisation? Elite Social Science Training in Stalinist Poland, "Minerva”, No. 34.

Czarny B., (1989a), Trzydzieści lat później (Lange Oskar: Dzieła, tom 8. Działalność naukowa i społeczna 1904-1965, PAN-PWE, Warszawa 1986), “Odra” No. 1.

Czarny B., (1989b), Dyskusja o racjonalności gospodarowania w polskiej literaturze ekonomicznej po II wojnie światowej, Warszawa (unpublished $\mathrm{PhD}$ thesis).

Czarny B., (2010), Pozytywizm a sądy wartościujące w ekonomii, Oficyna Wydawnicza SGH, Warszawa.

Czarny B., (2014a), O dorobku teorii ekonomii w Polsce w latach 1949-1989 - wstęp (forthcoming).

Czarny B., (2014b), Katedra Ekonomii Politycznej w Instytucie Kształcenia Kadr Naukowych i jej aspiranci, 1950-1953 (forthcoming).

Drabińska D., (1992), SGPiS w latach forsownych przeobrażeń społeczno-gospodarczych Polski 1949-1956, SGH, Warszawa (unpublished $\mathrm{PhD}$ thesis).

Drabińska D., (1994), Powstanie Szkoły Głównej Planowania i Statystyki, "Kwartalnik Historii Nauki i Techniki”, Vol. 39, No. 3-6.

Drewnowski J., (1974), Proces CUP, “Zeszyty Historyczne”, No. 28.

Drewnowski, J., (2000), Biografia naukowa, Londyn (retrieved 3.10.2013, from http://www.pte.pl/pliki/0/91/ Jan_Drewnowski.doc).

Dyskusja na II Zjeździe Ekonomistów Polskich (summary signed with initials H.Ch. i A.Ł.) (1956), “Ekonomista", No. 5.

Ekonomia polityczna socjalizmu (authors: R. Bauer, J. Beksiak, L. Biliński, W. Czech, S. Dulski, A.K. Koźmiński, U. Libura, Z. Marcinkowska, S. Nikołajczuk, S. Nowacki, H. Rębacz, B. Samojlik, A. Wernik) (1972), PWN, Warszawa.

Ekonomia polityczna socjalizmu (ed. M. Nasiłowski) (1974), KiW, Warsaw.

Fijałkowska B., (1985), Polityka i twórcy 1948-1959, PWN, Warszawa.

Gasman D., (1971), The Scientific Origin of National Socialism, New York.

Gazeta SGH, (1998), No. 84.

Godelier M., (1972), Rationality and Irrationality in Economics, Monthly Review Press, New York.

Grzelońska U., (1989), Wstęp, in: J.G. Zieliński, Rachunek ekonomiczny i zarządzanie w gospodarce socjalistycznej, Warszawa (retrieved 29.09.2013, from http://januszgzielinski.pl/_/Zycie.html).

Grzelońska U., (2006), 100 lat SGH i polska ekonomia, "Bank i Kredyt”, No. 5-6.

Hansson S.O., (2012), Science and Pseudo-Science, The Stanford Encyclopaedia of Philosophy (Winter 2012), ed. E.N. Zalta, (URL=http://plato.stanford.edu/archives/win2012/entries/pseudo-science/).

Haugstad A.W., (2008), A Discipline Divided. Polish Economists and the Communist Regime, 1945-1960, Norwegian University of Science and Technology, Trondheim.

Herczyński R., (2008), Spętana nauka. Opozycja intelektualna w Polsce 1945-1970, Wydawnictwo Naukowe Semper, Warszawa.

Hooloway D., (1974), Innovation in Science - the Case of Cybernetics in the Soviet Union, "Science Studies", No. 4.

Hübner P., (1992), Polityka naukowa w Polsce w latach 1944-1953. Geneza systemu, Vol. 1-2, Zakład Narodowy im. Ossolińskich, Wrocław i in.

Jarmulicz W., (1986), O przedmiocie i metodzie ekonomii politycznej w Polsce, Wers, Warszawa-Wrocław. 
Kalecki M., (1956), Sytuacja gospodarcza Stanów Zjednoczonych w zestawieniu z okresem przedwojennym, "Ekonomista", No. 4.

Kaliński J., (2006), SGH - od wieku na oceanie wiedzy, "Bank i Kredyt”, No. 5-6.

Kondek S.A., (1993), Władza i wydawcy. Polityczne uwarunkowania produkcji książek w Polsce w latach 1944-1949, Warszawa: Biblioteka Narodowa.

Kossecki J., (1999), Wpływ totalnej wojny informacyjnej na dzieje PRL, wydawnictwo nieznane, Kielce.

Kowalik T., (2008), Lange, Oskar Ryszard (1904-1965), in: The New Palgrave Dictionary of Economics (eds S.N. Durlauf, L.E. Blume), Palgrave Macmillan, Vol. 4.

Kurowski S., (1957), Nad ekonomią polityczną, in: S.J. Kurowski, Szkice optymistyczne, Pax, Warszawa.

Kurowski S., (2007), Obecne spojrzenie na II Zjazd Ekonomistów Polskich w 1956 roku, in: Przełomowy rok 1956 a współczesność (ed. Z. Sadowski), PTE, Warszawa.

Lakatos I., (1974), Science and Pseudoscience, in: Philosophy In the Open, (ed. G. Vesey), Open University Press.

Lange O., (1951), Zagajenie, “Ekonomista”, No. 1.

Lange O., (1953a), Prawa ekonomiczne socjalizmu, in: Zagadnienia ekonomii politycznej w świetle pracy Józefa Stalina pt. „Ekonomiczne problemy socjalizmu w ZSRR”, PWN, Warszawa.

Lange O., (1953b), Ostatni wkład Józefa Stalina do ekonomii politycznej, “Nauka Polska”, No. 2.

Lange O., (1986), Dzieła. T. 8, Działalność naukowa i społeczna: 1904-1965, PWE, Warszawa.

Lipiński E., (1947), Uwagi o zadaniach ekonomii, “Ekonomista”, No. 2.

Lipiński E., (1953), Przedmiot ekonomii politycznej i obiektywny charakter praw ekonomicznych, "Ekonomista", No. 1.

Lipiński E., (1956), O przedmiocie ekonomii i prawach ekonomicznych, "Ekonomista", No. 5.

Łukawer E., (2006), W nawiązaniu do idei i przekonań Michała Kaleckiego, in: Nierówności społeczne a wzrost gospodarczy. Problemy globalizacji i regionalizacji, część 1, Uniwersytet Rzeszowski, Katedra Teorii Ekonomii, Zeszyt No. 8, Rzeszów.

Mała Encyklopedia Ekonomiczna, (1961) (Editorial Board: Maksymilian Pohorille (Editor-in-Chief), Edmund Dąbrowski, Zbigniew Gajczyk, Bohdan Gliński, Jerzy Lubowicki, Kazimierz Łaski, Mirosław Orłowski, Wiesław Sadowski, Paweł Sulmicki, Józef Zagórski, Zygmunt Zaremba, Józef Zawadzki, Seweryn Żurawicki), PWE, Warsaw.

Mała Encyklopedia Ekonomiczna, (1974) (Editorial Board: Kazimierz Secomski (Editor-in-Chief), Henryk Chołaj, Zdzisław Fedorowicz, Bohdan Gliński, Zygmunt Knyziak, Mirosław Orłowski, Leszek Pasieczny, Maksymilian Pohorille, Wiesław Sadowski, Józef Sołdaczuk, Paweł Sulmicki, Jan Szczepański, Józef Zagórski, Seweryn Żurawicki), PWE, Warsaw.

Marosz M., (2008), Obywatelski obowiązek profesora, “Gazeta Polska”, No. 40.

Mieszczankowski M., (1987), Ekonomia (zarys popularny), KiW, Warsaw.

Minc B., (1949), Zarys podstawowych zagadnień ekonomii politycznej, cz. 1, Akademicka Spółdzielnia Wydawnicza, Warsaw.

Orłowska J., Orłowski T., (1985), Polskie Towarzystwo Ekonomiczne. Zarys historii, PTE, Warszawa.

Osiatyński J., (1984), Przypisy i dodatki, in: M. Kalecki, Dzieła, Vol. 4, Socjalizm. Wzrost gospodarczy i efektywność inwestycji, PWE, Warszawa.

Ostrowitianow K.W. (et al.), (1955), Ekonomia polityczna socjalizmu. Podręcznik. (translation from Russian edited by: S. Żurawicki, J. Zawadzki, R. Gradowski, R. Winiewska, M. Pohorille), KiW, Warsaw. 
Pajestka J., (1980), Świadome kształtowanie procesów społeczno-gospodarczych w gospodarce socjalistycznej, in: Racjonalność gospodarowania w socjalizmie (eds B. Kamiński, A. Łukaszewicz), PWE, Warszawa.

Pajestka J., (1982), Państwo a gospodarka i społeczeństwo, “Gospodarka Planowa”, No. 9.

Pajestka J., (1988), Postawy cywilizacyjne w procesie rozwoju, “Ekonomista”, No. 2.

Patinkin D., (1981), Essays on and in the Chicago Tradition, Duke University Press, Durham.

Rafa J., (1988), Myśl ekonomiczna III Rzeczpospolitej do 1985 r., nieznane wydawnictwo, Warszawa (copy in author's possession).

Ratajczak M., (2009), Polish Economics and the Polish Economy: A study for the Twentieth Anniversary of Transition in Poland, "The History of Economic Thought", Vol. 51, No. 2.

Sadzikowski W., (1969), Ekonomia polityczna kapitalizmu, PWN, Warsaw.

Sawicki W., (2002), Stasi a opozycja demokratyczna w Polsce 1976-1989, in: Raport Kiszczaka dla Moskwy, Fundacja Centrum Dokumentacji Czynu Niepodlegościowego, Kraków.

Schaff A., Brum L., (1950), Pogadanki ekonomiczne, KiW, Warsaw.

Skiba L., (1998), Ekonomia po dominacji marksistowskiej a przemiany ustrojowe, in: Ekonomia w Polsce po dominacji marksistowskiej. Studia i materiały (ed. L. Skiba), Wydawnictwo DTSK Silesia, Wrocław.

Smyrgała D., (2009), Polscy agenci Stalina, "Wprost”, No. 12.

Szarek J., (2000), Strażnik komunistycznego systemu, "Arcana”, No. 4.

Taylor E., (1947), Wstęp do ekonomiki, Spółdzielnia Wydawnicza “Żeglarz”, Gdynia.

Temkin G., (1952), O roli państwowej własności socjalistycznej w świetle projektu Konstytucji Polskiej Rzeczpospolitej Ludowej, "Ekonomista”, No. 2.

Temkin G., (1962), Karola Marksa obraz gospodarki komunistycznej, PWN, Warszawa.

Thagard P.R., (1978), Why Astrology Is a Pseudoscience, Philosophy of Science Association: "Proceedings of the Biennial Meeting of the Philosophy of Science Association", Vol. 1978, Volume One: Contributed Papers, The University of Chicago Press.

Tyrowicz S., (2009), Światło wiedzy zdeprawowanej. Idee niemieckiej socjologii i filozofii (1933-1945), Universitas, Kraków.

Uchwała II Zjazdu Ekonomistów Polskich w Warszawie w dniach 7-10 czerwca 1956 r. (1956), "Ekonomista", No. 5 .

Voren R.V., (2010), Cold War in Psychiatry: Human Factors, Secret Actors, Rodopi, Amsterdam, New York.

Wagener H.-J., (1997), Second Thoughts? Economics and Economists under Socialism, "Kyklos", Vol. 50, Fasc. 2 .

Wagener H.-J., (1998), Between Conformity and Reform. Economics Under State Socialism and Its Transformation, in: H.-J. Wagener (ed.) Economic thought in communist and post-communist Europe, Routledge, London, New York.

Wiles P., (1965), Political Economy, Volume I: General Problems. By Oskar Lange, “Political Science Quarterly”, Vol. 80, No. 1.

Zieliński G.J., (1973), Economic Reforms in Polish Industry, London, pp. xix-xxii (retrieved 4.04.2013, from http://januszgzielinski.pl/_/credo_naukowe.html).

Z.Ż., (1998), Nauka polska po komunizmie, "Myśl Polska”, No. 31. 